\title{
Outi Paloposki
}

\section{Suomentaminen, korjailu, toimittaminen Esimerkkinä Les Misérables -romaanin suomennokset}

Uudelleenkäännöksiä käsittelevä tutkimus on pitkään keskittynyt sen väitteen toistamiseen, että uudet käännökset ovat "parempia" ja lähempänä alkutekstiä kuin ensikäännökset ja että uudelleenkäännöksiä tarvitaan, koska käännösten kieli vanhenee ja uudet sukupolvet tarvitsevat ajantasaistetut versiot klassikkoteoksista. Artikkeli käsittelee niitä tekstuaalisia ilmiöitä ja tämänkaltaisen tutkimuksen ongelmakohtia, joita on tullut eteen yhtä uudelleensuomennettua teosta, Victor Hugon Kurjia, tarkasteltaessa. Tutkimus on osa laajempaa yhdessä Kaisa Koskisen kanssa rakentamaamme hanketta, jossa olemme keränneet erilaisia aineistoja uudelleensuomennoksista, niiden taustoista, vastaanotosta ja eroista. Olimme lähtökohtaisesti kiinnostuneita siitä, miksi jostain teoksesta tarvitaan useita versioita. Väitteet käännöksen vanhentuneisuudesta ja uuden, ajanmukaisen käännöksen tarpeesta eivät tunnu läheskään aina vastaavan uudelleenkäännöstilannetta, vaan taustalla on paljon monimutkaisempia syitä. Uudelleenkäännökset ovat kuitenkin nostaneet esiin myös toisen ilmiön, uusintapainokset, ja nämä puolestaan herättäneet huomaamaan sen toimitus-, korjaus- ja uusimistyön, mikä usein jää piiloon uusintapainoksista puhuttaessa. Käännösten muokkaaminen ensimmäisen painoksen jälkeen on varsin yleistä, ja tähän editointiin liittyy paljon sellaista, mikä voi kertoa myös yleisesti suhteestamme teoksiin, kieleen, kirjailijaan ja kääntämiseen.

Vanhojen käännösten muokkaamista on joskus pidetty vain ensimmäisenä vaiheena ennen uuden käännöksen tekemistä (esim. Vanderschelden 2000), mutta suomennosten historiassa on useita esimerkkejä käännöksistä, joihin on tehty laajojakin muutoksia vuosien ja vuosikymmenien varrella ja joita silti ei koskaan ole käännetty uudestaan, vaikka ensimmäinen käännös olisi jo sata vuotta vanha. Tällaisia ovat esimerkiksi jotkut Julius Krohnin ja Maila Talvion käännökset, Eino Leinon Anatole France -suomennos Kuningatar Hanhenjalan ravintola vuodelta 1910 ja monet muut vuosisadan vaihteen klassikot, erityisesti nuorisoromaanit. Toisaalta uudelleensuomentaminen ja vanhan suomennoksen editoiminen voivat myös kulkea käsi kädessä ja kietoutua toisiinsa monin tavoin. Esimerkki tällaisesta monipolvisesta suomennoshistoriasta on Victor Hugon romaanin Les Misérables suomentamisen vaiheet. 


\section{Kurjien julkaisuhistorian alku Suomessa (1896-1897)}

Les Misérables ilmestyi ranskaksi vuonna 1862. Teos oli laaja ja polveileva. Hugo oli rakentanut romaanin viisiosaiseksi, joista jokainen osa (partie) jakautui edelleen kirjoiksi (livre), nämä taas luvuiksi (chapître), joita yhteensä on 365. Osien nimet on mainittu lähdeluettelossa. Myöhempää lukijaa saattaa hämmentää se, että tämä romaanin sisäinen jako ei näy kaikissa versioissa. Teosta ei aina ole sidottu osien mukaan, vaan vihkosina ilmestyneet, satunnaisiin kohtiin katkeavat romaanijaksot on saatettu koota ensin pienemmiksi vihkoiksi ja sitten sitoa kirjoiksi, jotka nekään eivät välttämättä noudattaneet osajakoa. Niinpä käyttämäni Brysselissä painettu vuoden 1862 laitos on nidottu 17 niteeseen (tome), jotka puolestaan on sidottu neljäksi kirjaksi; ensimmäinen ruotsinnos samalta vuodelta on jaettu 10 sidokseen.

Hugon teokset levisivät Euroopassa nopeaa vauhtia belgialaisten piraattipainosten ansiosta (ks. Häggman 2008, 90), ja Les Misérables käännettiin jo ilmestymisvuonna useille kielille, muun muassa ruotsiksi. Victor Hugo olikin Suomessa tunnettu ensin ruotsinnosten kautta. Ensimmäinen tunnettu suomennos Hugon teoksista oli Pietari Hannikaisen julkaisemattomaksi jäänyt Hernani vuodelta 1870; se on talletettu SKS:n kirjallisuusarkistoon ja digitaalisesti Kotimaisten kielten tutkimuskeskuksen Kainotietokantaan. Silva Kiuru (s.a.) on arvellut Hernanin ruotsinkielisten esitysten Helsingissä 1870-luvulla saattaneen innostaa Hannikaista suomennostyöhön. Suomennos kuitenkin lienee tehty alkuteoksesta, koska käsikirjoitukseen on tehty ranskankielisiä merkintöjä. Vuonna 1833 ilmestynyt ruotsinkielinen mukaelma ei Kiurun mukaan ole voinut olla Hannikaisen näytelmän esikuva.

Hugo herätti ristiriitaisia tunteita Suomessa. Jo Lucrezia Borgian ruotsinnos kirvoitti Runebergilta ankaran arvion Morgonbladetiin, ja myöhemmin Kirjallinen Kunkauslehti ja sen piirissä toimivat olivat nihkeitä Hugoa kohtaan. Suomalaisen teatterin johtaja Kaarlo Bergbom arvosteli Hugoa "sanarikkaasta pöyhkeilystä" (Lehtonen 1917, 69-70), ja K. G. S. Suomalainen $(1884,1)$ vertasi Eugene Suen ja Victor Hugon kirjoituksia myrkkyyn kultaisissa kupeissa. Ranskasta ajateltiin tulevan "siveydentunnetta" loukkaavia teoksia (Tuominen 2004, 349), mutta sieltä oli kuitenkin 1800-luvun puolivälistä lähtien suomennettu esimerkiksi Alexandre Dumas'ta ja Jules Verneä, ja myös Hugoa esitettiin Suomalaisessa teatterissa: Maria Tudor 1873 ja Angelo 1878 (Sakari 1986, 91). Hugo, Sue ja varsinkin Zola olivat usein konservatiivisten kirjoittajien hampaissa, eikä kukaan näistä päässyt Suomalaisen Kirjallisuuden Seuran vuoden 1870 listaamiin käännöstoiveisiin toisin kuin esimerkiksi Molière, Bernardin de Saint-Pierre, Chateaubriand ja Madame de Staël. Victor Hugon muistokirjoituksen kirjoittaja Werner Söderhjelm (1885) kuitenkin kehuu myös Hugon ansioita, vaikka kirjoituksesta ei kriittistä sävyäkään puutu - kritiikki on tässä kuitenkin pikemminkin kirjallista kuin moraalista. 
Les Misérables aloitti Hugon romaanien historian Suomessa 1800-luvun viimeisellä vuosikymmenellä, kymmenen vuotta Hugon kuoleman jälkeen. Teosta lähdettiin julkaisemaan Tampereella sekä ruotsiksi että suomeksi. Vihkomuoto oli yleinen ilmestymistapa romaaneille 1800-luvun Euroopassa, ja näin Suomessakin aluksi julkaistiin monet romaanit, myös Kurjien ensilaitokset. Yhden painoarkin eli 16 sivun kokoisina vihkoina painettuja teoksia pyrittiin myymään lukijoille jatkokertomusten tapaan; ostajille oli edullisempaa hankkia kirjat vihko kerrallaan ja vasta lopuksi sidotuttaa ne yhteen. Jatkokertomuksiin lukijat jäivät myös helposti koukkuun.

Vihkopainannan vuoksi toisaalta myös teosten julkaisu saattoi joskus jäädä kesken. Hugon romaanista ilmestyi ruotsinkielisenä vain alku, 112 sivua, nimellä Sambällets olycksbarn vuonna 1895 ja suomenkielisenäkin vain osa, 448 sivua, nimellä Yhteiskunnan onnettomat vuosina 1896-1897. Ensimmäinen suomenkielinen Kurjien laitos ei siis kata edes teoksen koko ensimmäistä osaa, vaan päättyy sen kahdeksannen kirjan neljännen luvun alkuun. Oliko kustantaja tehnyt virhearvion ryhtyessään julkaisemaan käännöstä? Juuri ennen Kurjien julkaisuhistorian alkua Suomessa oli ilmestynyt Alexandre Dumas'n Monte Criston kreivistä ensimmäinen suomennos (1892, suom. J. A. Saivo), samoin Eugène Suen Kuljeksiva juutalainen oli parhaillaan ilmestymässä (1895-1896, suom. samoin J. A. Saivo), ja ranskalaisille mammuttiromaaneille ajateltiin ehkä olevan menekkiä. Kustantaminen oli 1800-luvulla vielä riskialtista, joskin houkuttelevaa lukijakunnan nopean kasvun vuoksi, ja kustannustoimintaan vaikuttivat monet tekijät (ks. Häggman 2008, 190-191). Ainakaan nopeaa voittoa ei Hugon romaani ensimmäisille suomalaisille kustantajilleen tuonut. Levityksessä oli kyllä pyritty maanlaajuiseen kattavuuteen ja varmasti sitä myötä takaamaan menekki ja kattamaan painatuskulut: suomennoksen alkuun on painettu tieto, että "asiamiehiä halutaan kaikkialta”. Riittävää verkostoa ja kysyntää ei liene kuitenkaan saavutettu.

Vuoden 1895 ruotsinkielisessä laitoksessa ei mainita kääntäjää. Yhteiskunnan onnettomien suomentajaksi on merkitty nimimerkki J. J., jonka taakse kätkeytyy todennäköisesti Juho Jäykkä (J. Aulén). Hänen kohtalaisen runsas suomennostoimintansa käsitti myös ranskalaista kirjallisuutta, joskin ruotsin kautta suomennettuna.

Näiden kahden käännöksen nimien samankaltaisuus antaa vahvan oletuksen käännösten välisestä suhteesta, samoin se seikka, että sekä ruotsinnos että suomennos ilmestyivät Tampereella ja ajallisesti varsin lähekkäin. Ongelmia aiheuttaa kuitenkin se huomio, että ruotsinnos oli paljon lyhyempi kuin suomennos - suomennosta ei siis ole voitu tehdä ainakaan painetusta laitoksesta. ${ }^{1}$

Tukholman Kungliga Bibliotekissa säilytettävät ruotsinnokset antavat lisävalaistusta asiaan. Ruotsissa vuosina 1862 ja 1888-1889 ilmestyneet käännökset olivat molemmat nimeltään Sambällets olycksbarn. Otsikko on siis peräisin jo ensimmäisestä ruotsinnoksesta. Ruotsintaja C. J. Backman oli muokannut otsikon tavalla, joka toisaalta oli luova 
ja omaleimainen (UNESCOn Index Translationumin käännöstietokannan mukaan ainakaan millään muulla skandinaavisella, germaanisella tai romaanisella kielellä ei teosta ole nimetty tämänkaltaisesti) ja toisaalta loi pohjan pitkälle nimeämisperinteelle: kaikki tämän jälkeenkin Ruotsissa ilmestyneet teoksen käännökset ovat samannimisiä. Molemmat varhaiset ruotsinnokset ilmestyivät L. J. Hiertan kustantamina, mutta vain ensimmäisen kääntäjä tunnetaan. Tekstivertailu näiden kahden ruotsinnoksen välillä kuitenkin osoittaa, että jälkimmäinen ei ole uusintapainos, vaan kyseessä on todella kaksi eri käännöstä.

Vertailu suomalaisteksteihin puolestaan kertoo, että Tampereen ruotsinkielinen käännös ei ollut itsenäinen käännös vaan se on ladottu vuosien 1888-1889 ruotsalaisesta laitoksesta. Laitosten välillä on eroja ainoastaan muutamien ladontavirheiden sekä alaviitteiden osalta. Erojen perusteella voidaan myös päätellä, että se konkreettinen teksti, joka suomentajalla oli edessään, ei ollut Tampereella painettu ruotsinnos vaan Ruotsissa 1888 ilmestynyt ensimmäinen osa. Esimerkiksi Ruotsissa ilmestyneessä laitoksessa on alaviitteitä, joita ei ole otettu mukaan Tampereella painettuun ruotsinkieliseen laitokseen, mutta jotka on käännetty suomennokseen. Suomentaja on todennäköisesti ollut tietoinen myös Tampereen ruotsinkielisen painoksen ilmestymisestä; kenties hän jopa käännöstä tehdessään käytti teoksen samaa ruotsalaista kappaletta kuin ruotsinkielisen painoksen latoja. Molempien painatushankkeiden takana ovat tietenkin saattaneet olla samat henkilöt.

Seuraavat katkelmat, jotka tässä esitetään allekkain vertailun helpottamiseksi, osoittavat syntaktisine samankaltaisuuksineen, että suomennos on tehty ruotsinnoksesta eikä suoraan ranskasta. Suomennos on ladottu fraktuuralla, jossa w-kirjain oli yleisesti käytössä v:n merkkinä, ja se on säilytetty tässä. Kaikki ruotsinnokset ja myös kaikki myöhemmät suomennokset sen sijaan on ladottu antiikvalla. ${ }^{2}$

Plötsligt kom så revolutionen, händelserna följde brådstörtadt på hvarandra, Äkkiä tuli kapina, tapaukset seurasiwat nopeasti toinen toistaan,

parlamentsfamiljerna, decimerade, förjagade, efterspanade, skingrades åt alla håll. parlamenttiperheet, harwennettuina, karkoitettuina ja wainottuina, hajaantuiwat kaikille suunnille.

Redan under revolutionens första dagar utvandrade Charles Myriel till Italien. Jo kapinan ensi päiwinä waelsi Charles Myriel Italiaan.

Hans hustru dog der af en bröstsjukdom, hvaraf hon länge lidit. De hade inga barn. Hänen waimonsa kuoli siellä rintatautiin, jota hän jo kauwan oli sairastanut. Heillä ei ollut yhtään lasta. 
Hvad hade sedan tilldragit sig i Myriels lif? Hade det gamla franska

Mitä oli sitten tapahtunut Myrielin elämässä? Oliko tuon wanhan ranskalaisen

samhällets omstörtande, hans egen släkts fall och 1793 års

yhteiskunnan kumoutuminen, hänen oman perheensä perikato ja 1793 wuoden

sorgliga händelser, kanske ännu förfärligare för emigranterne, hvilka sågo dem

surulliset tapaukset, ehkä wielä hirwittäwämmät siirtolaisille, jotka näkiwät niitä

på långt håll genom förskräckelsens förstoringsglas, hade allt detta hos honom väckt kaukaa kauhistuksen suurennuslasien läpitse, onko tämä kaikki herättänyt hänessä

tankarna på försakelse och ensamhet?

kieltäymyksen ja yksinäisyyden ajatuksia? (Hugo 1888, 9; Hugo 1896, 8.)

Sen lisäksi, että suomennoksen lauserakenteet seurailevat tarkkaan ruotsinnosta, ovat vuosiluku 1793 (ranskankielisessä tekstissä vain 93) ja "suurennuslasi”-sanan käyttäminen merkkejä ruotsinnoksen ja suomennoksen yhteydestä. Tampereella painettu ruotsinnos oli tekstiltään sama, mutta siitä oli jätetty pois suuri osa ruotsinkielisen laitoksen alaviitteistä. Näitä alaviitteitä on suomennoksessa kuitenkin hyödynnetty, mikä myös puoltaa sitä oletusta, että suomentajan alkutekstinä oli ollut Ruotsissa vuosina 1888-1889 tehty laitos.

Esimerkiksi Tukholmassa painetun Sambällets olycksbarn -ruotsinnoksen tekstikohtaan "äta sothöns" on lisätty viite "Anspelar på ett sätt att kringgå förbudet att äta kött om fredagarna, enär sothönan som sjöfågel fick äran räkna slägtskap med den tilllåtna fisken. ö.a." (Hugo 1888, 93). Yhteiskunnan osattomat -suomennoksen vastaavaan tekstikohtaan ("syöwät nokikanoja") on lisätty ruotsista käännetty viite "Tarkoittaa lihan syönnin kieltoa perjantaina, koska nokikana wesilintuna, sai kunnian olla luwallisen kalan sukulainen” (Hugo 1896, 69). Sen sijaan vuoden 1895 ruotsinnoksessa kyseiseen tekstikohtaan ei ole lisätty selitystä.

Suomentamiensa alaviitteiden lisäksi J. J. on myös tehnyt omia lisäyksiä. Niiden sijoittelussa hän näkyy ottaneen opikseen aiemmin Yrjö Koskiselta saamastaan kritiikistä Sara Wacklin -suomennoksensa Satanen muistelmia Pohjanmaalta (1872-1876) yhteydessä. Koskinen $(1877,34)$ oli arvostellut Kirjallisessa Kuukauslehdessä suomentajaa siitä, että tämä oli "tehnyt tekstiin lisäyksiä, jotka korkeintaan olisivat saaneet käydä eri muistutuksina viivan alla”. Hugon romaanissa J. J. on sijoittanut lisäyksensä alaviitteiksi. Niiden sisällöstä voi myös päätellä, mitä tietoa J. J. on ajatellut nimenomaan suomalaisen lukijan tarvitsevan. Esimerkiksi giljotiinista on tehty tällainen selitys.

Suomennoksen kieli oli syntaktisesti hyvin lähellä lähtötekstiä. Tämä näkyy J. J.:n muissakin suomennoksissa, ja tätä lienee Koskinen myös tarkoittanut todetessaan Wacklin- 
käännöksestä, että se "ei ole huolellisesti hoidettu, vaikka kyllä helppo ymmärtää". Tämänkaltainen kääntäminen ei ollut mitenkään erityisen poikkeavaa 1800-luvun loppupuolella, vaan alkutekstiä seurailevaa kieltä oli paljonkin; siihen myös kiinnitettiin huomiota kritiikeissä (Paloposki 2007, 120-124). Tällaisen kääntämisen ei kuitenkaan voi väittää olleen tyypillistä, koska tyypillisyydestä ei ylipäätään voi puhua 1800-luvun kirjakielen kohdalla. Kirjakielen muoto(j)a haettiin vuosisadan alkukymmeninä voimakkaammin kuin loppuvuosina, mutta läpi koko vuosisadan käännöskirjallisuuden kieltä voi luonnehtia monimuotoiseksi ja vaihtelevaksi. Toiset suomentajat - kuten edellä mainittu Samuli Suomalainen - pyrkivät irtautumaan alkutekstistä ja etsimään suomen kielelle ominaisia rakenteita. Joskus se johti sisällön kotouttamiseen tai erilaisiin adaptaatioihin. Toiset taas noudattivat hyvinkin tarkkaan käyttämänsä alkutekstin kielen mukaisia ratkaisuja, oli se sitten alkuperäinen teos tai jokin sen erikielisistä käännöksistä. Tämä ilmenee erityisesti lauserakenteiden kopiointina ja osin myös vierassanoina. Näihin alkukielen seurailijoihin kuului myös Juho Jäykkä.

\section{Kurjien toinen käännösyritys (1908-1909)}

Kymmenen vuotta myöhemmin Kurjia ryhdyttiin suomennuttamaan Kansan romaanikirjastoon. Tarkoituksena oli suomentaa koko viisiosainen teos, minkä voi päätellä vuosina 1908-1909 ilmestyneiden vihkosten takakanteen merkityistä kokonaissivumäärästä. Vihtori Lehtosen suoraan ranskasta tehtyä käännöstä ilmestyi kuitenkin vain kaksi ensimmäistä osaa (Fantine ja Cosette), ja Cosette jäi koko Kansan romaanikirjaston viimeiseksi niteeksi. Suomalainen Kustannus OY Kansa, jonka johtokuntaan kuului varsin nimekkäitä henkilöitä (mm. A. W. Koskimies, Ernst Nevanlinna, Gunnar Suolahti), eli vain muutaman vuoden huolimatta kunnianhimoisista julkaisupyrkimyksistä (Virtanen 1958, 232; Zweygbergk 1958, 154).

Tämä vuosina 1908-1909 ilmestynyt suomennos julkaistiin sillä nimellä, jolla se nykyisinkin Suomessa tunnetaan, Kurjat. Siihen oli liitetty nimimerkki H.:n allekirjoittama 8-sivuinen esipuhe, jossa valotettiin Hugon elämää, kirjallisia vaikutteita, tuotantoa, Kurjien syntyhistoriaa ja sen sanomaa. ${ }^{4}$ Esipuheen lisäksi vihkosten takakansitekstit mainostivat teosta pitkällä kuvauksella, joka alkoi seuraavasti: "Laajin ja suurenmoisin romaani mitä suomeksi vielä on ilmestynyt, on 'Kurjat', maailmankirjallisuuden merkkimiehen leimuava taistohuuto yhteiskunnan lapsipuolten edestä.”. Kolmannen vihon takakannessa henkilöhahmojen kuvailua jatketaan, ja romaanista todetaan vielä: "'Kurjat' on teos kaikille piireille. 'Jumalainen luoma', lausuu sen suomentaja". Vihkomuoto oli oiva tapa teoksen mainostamiseen, koska jännittäviä juonikäänteitä pystyttiin käyttämään takakansiselostuksissa ja näin ne houkuttelivat uusia lukijoita. Kirja ei päässyt heti unohtumaan asiamiehiltäkään, joita muistutettiin neljännessä vihkossa (kursivointi alkuperäisessä): "kenenkään ei pitäisi jättää käyttämättä tilaisuutta tutustua 
tähän suuremmoiseen nerontuotteeseen [- - $N y t$ on hetki sen tilaamiseen vielä käsissä. Asiamiehillä on nyt parhain toimikautensa."

Kurjien käännöstyöstä ei ole mainintoja Kansalliskirjaston ja Suomalaisen Kirjallisuuden Seuran kokoelmissa säilytettävissä Vihtori Lehtosen kirjeissä, joten ristivalotusta Kurjien tämän suomennoksen syntyhistoriaan ei sieltä löydy. Kirjeistä Kaarle Krohnille vuosina 1908-1910 välittyy kuitenkin kuva kirjallisesta monitoimijasta, joka ei vielä tiedä, mihin suuntautuisi:

Kaikenlainen kirjallisuus on minut sitonut, siihen olen minä aikoinani ollut innostunutkin, sitä minä olen käänneskellyt leipätöikseni ja elänyt siten omin neuvoineni jo kolme vuotta, sitä olen pyrkinyt ymmärtämään. En tiedä, onko minua siinä ohjannut sattuma taas, vaiko todellinen kiintymys, pää-asia vain on, että muuhun ei ole juuri harrastusta riittänyt. (Lehtosen kirje Kaarle Krohnille 27.7.1909.)

Lehtosen myöhemmän uran tuntijoita kiinnostaneekin kirjeestä kuultava epävarmuus: "mistä se [väitöskirja] on kirjoitettava? Laitani on tosiaankin niin hullusti, ettei minulla ole erityisempää kiintymystä mihinkään 'tieteen' lajiin, koska en luule itsestäni todellista tiedemiestä koskaan tulevan”. (Lehtosen kirje Kaarle Krohnille 27.7.1909.)

Mitä itse käännökseen tulee, Lehtonen ei selvästikään pyrkinyt seurailemaan alkutekstin lauserakennetta, vaan lienee tähdännyt elävämpään ja vapaampaan suomen kieleen. Esimerkkinä Lehtosen tyylistä sama katkelma teoksen alusta kuin edellä ruotsinnoksesta ja Jäykän aiemmasta suomennoksesta:

Iski vallankumouksen salama, tapaukset seurasivat nopeasti toisiaan, virkamiesperheet hajosivat sinne ja tänne, huvenneina, vainottuina, hätyytettyinä. Heti vallankumouksen alkaessa pakeni Charles Myriel Italiaan. Siellä kuoli hänen vaimonsa rintatautiin, joka oli häntä jo kauvemman aikaa vaivannut. Heillä ei ollut lapsia. Minkälaisen käänteen sai sitten herra Myrielin kohtalo? Saivatko Ranskan vanhan yhteiskunta-järjestyksen sortuminen, hänen oman perheensä häviö, 1773:n [sic] hirmutapahtumat, jotka etäämmältä asiaa seuraavain maanpakolaisten kauhu teki ehkä vieläkin hirvittävämmäksi, saiko kaikki tuo itämään hänen mielessään varjoon vetäytymisen ja yksinäisyyden ajatuksia? (Hugo 1909, 8.)

Teoksen kahdella ensimmäisellä suomennoksella on ajallisesti vain vuosikymmenen verran eroa, ja tyylilliset eroavuudet kertovatkin juuri siitä, että aikakauteen mahtui monenlaista kääntäjän kynänjälkeä ja työskentelytapaa. Alkuteosvalinta on yksi kääntäjän työn lähtökohtia, ja Lehtosella ranskankielisen tekstin käyttö näkyy esimerkiksi siinä, miten hän oli pyrkinyt säilyttämään tekstin moniäänisyyttä ja puhekielen variantteja. Hän on jättänyt käännökseensä ranskalaisen alkutekstin murrenäytteitä, jotka kuvaavat piispa Bienvenun (sitaatissa mainittu Charles Myriel) taitoa käyttää murteita kansanjoukossa. Juho Jäykkä ei olisi voinut murrekohtia millään tavoin säilyttää tai korvata, koska niitä ei hänen lähdetekstinä käyttämässään ruotsinnoksessakaan 
ollut. Myös irtaantuminen aiempien ruotsinnosten tyylistä kertoo Lehtosen käyttäneen ranskankielistä tekstiä, vaikka on tietenkin mahdollista, että hänellä oli muitakin käännöksiä käytössään. Lehtonenkin käytti lukuisia alaviitteitä selittääkseen suomalaisille lukijoille tekstin monia viitteitä katolisen kirkon käytäntöihin, Ranskan vallankumoukseen, ulkomaisiin tiedemiehiin ja niin edelleen. Alaviitteet ovat osin eri paikoissa ja selittävät eri ilmiöitä kuin aiempien ruotsinnosten ja Jäykän suomennoksen alaviitteet. Toisessa osassa alaviitteiden määrä vähenee, mikä on yleinen ilmiö: niitä on usein eniten tekstin alkupuolella, osittain varmasti siksi, että vieraiden asioiden toistuessa niitä ei tarvitse enää uudelleen selittää, mutta ilmiölle on toki ajateltavissa muitakin syitä (ks. Paloposki 2010, 98).

Nuoren Lehtosen suomennokset herättivät positiivista vastakaikua. Kurjia ei käsitelty Valvoja-lehdessä, jonka sivuilla arvioitiin monia suomennettuja teoksia tuoreeltaan, mutta Valvojassa on muita viittauksia Lehtoseen suomentajana. Lehtosen tyyli sai kiitosta esimerkiksi nimimerkki V. T.:ltä (Viljo Tarkiainen, 1909, 520), joka kiitteli Lehtosen kääntäjäntaitoja tämän suomentaman Juan Valeran Kiusaus-romaanin (1908) yhteydessä seuraavasti: "Suomennos on yleensä sujuvaa ja tyylikästä. Maisteri Lehtosesta on saatu hyvä lisä kelvollisten suomentajiemme harvalukuiseen joukkoon.” Ennen yliopistollista uraansa Lehtonen suomensi Vihtori Lehtosen nimellä suuren joukon kirjallisuutta romaanisista kielistä ja englannista. Vasta myöhemmin, kun hänestä tuli kirjallisuuden professori, ranskalaisen kirjallisuuden tuntija ja myös arvostettu Aleksis Kivi -tutkija, hän ryhtyi käyttämään nimeä J. V. Lehtonen. Hänen väitöskirjansa vuonna 1913 käsitteli ranskalaista Théophile Gautier’ta, ja Hugosta hän kirjoitti kymmenisen vuotta suomennostyönsä jälkeen Werner Söderströmin sarjaan Merkkimiehiä (Lehtonen 1917). Kurjien seuraavan laitoksen aikoihin J. V. Lehtonen oli valmistelemassa päätoimittajana Otavalle uutta maailmankirjallisuuden historian yleisesitystä; hän olisi itse vastannut Ranskan kirjallisuuden osuudesta. Suunnitelma ei kuitenkaan koskaan toteutunut. (Tarkka 1980, 157.)

\section{Koko teoksen käännös (1927-1931)}

Kurjat otettiin WSOY:n julkaisuohjelmaan 1920-1930-lukujen taitteessa ja se ilmestyi Valiokirjasto-sarjassa. Ensimmäinen osa "Fantine” julkaistiin Lehtosen käännöksenä ja hänen nimellään, mutta sen kieliasu tarkistettiin (tarkistajasta ei ole tietoa). Lehtosen suomennoksen toista osaa ei jostain syystä kuitenkaan enää korjattu, vaan Eino Voionmaa teki siitä sekä kolmesta vielä kääntämättömästä osasta uuden suomennoksen. Tässä vuosina 1927-1931 ilmestyneessä laitoksessa nidokset vastaavat Hugon alkuperäistä osajakoa. Tämä on myös ainoa suomeksi täysin kokonaisena ilmestynyt Kurjien laitos. Suomentajina on mainittu sekä Lehtonen että Voionmaa; tähän laitokseen perustuvan lyhennelmän uusintapainoksissa kääntäjätiedot sen sijaan ovat puutteellisia. 
WSOY:n historian vuoteen 1928 asti kirjoittanut Yrjö Jäntti $(1928,312)$ totesi tuoreeltaan, että Valiokirjaston luominen oli "kustannusliikkeen johdon rakkaimpia ajatuksia", ja korosti sarjan pyrkivän julkaisemaan "taiteellisesti ja kirjallishistoriallisesti parasta ja klassillisinta koti- ja ulkomaista kaunokirjallisuutta". Kustantamon linjana olikin 1920-luvulla jatkaa käännöskirjallisuuden ja klassikoiden julkaisemista riippumatta isänmaallisuuden aallosta, joka tuolloin alkoi olla vallalla kustannusmaailmassa (Häggman 2001, 358-360). Menekki pyrittiin takaamaan muun muassa pyytämällä vakituiseksi avustajaksi V. A. Koskenniemi, joka kirjoitti alkulauseet julkaistaviin kirjoihin, minkä lisäksi yhtiö laski "parhaiden suomentajavoimien" varaan. Kurjien julkaisemisesta Jäntti kirjoitti (mt., 318), että ”[p]aljoa ei ole tahdottu suomennuttaa, mutta sensijaan vain ensiluokkaista ja arvokasta. Sellainen yritys kuin 'Kurjien', 'maailman suurimman romaanin' suomennuttaminen vastaa jo yksinään useita kymmeniä pikkunäpertelyjä.” Kurjat saatiinkin nyt julkaistuksi täysimittaisena, mutta Valiokirjaston kohtalo oli sama kuin Kansan romaanikirjaston, edellisen Kurjia julkaisseen sarjan. Valiokirjasto lakkautettiin menestymättömänä muutaman vuoden päästä (Hellemann 2007, 339).

Romaanisuomennosten kieli oli 1900-luvun alkupuolella vielä paljon esillä Virittäjän kaltaisissa aikakauslehdissä. Kustantamotkin saivat usein kuulla kunniansa, jos niiden kustannustuotteiden kieltä pidettiin huonona. Kielenhuolto oli yhtäältä joidenkin instituutioiksi muodostumassa olevien elinten, kuten Kotikielen Seuran sekä Suomalaisen Kirjallisuuden Seuran ja erityisesti sen Kielitieteellisen osakunnan, ja toisaalta yksittäisten kirjoittajien käsissä (Kangas 1988, 41-42). Suomen kieltä pyrittiin myös standardisoimaan ja kodifioimaan, ja vanhempia suomennoksia pidettiin usein kielellisesti vanhentuneina. Monia 1800-luvun puolella tehtyjä suomennoksia korjailtiin 1910-1930-luvuilla, jolloin monia teoksia käännettiinkin uudelleen. Ei ole helppoa tehdä yleistystä siitä, minkälaiset kirjat päätyivät uudelleen suomennettaviksi, mitkä taas korjattaviksi. Osittain päätöksiin on varmasti vaikuttanut resurssien vähyys, kun on ajateltu korjaamisen olevan nopeampaa ja taloudellisempaa kuin uudelleen käännättäminen. Tosin monet suomentajat ovat vuosikymmenien varrella kirjoittaneet toisilleen tai kustantajille, että vähemmällä vaivalla ja mieluummin olisivat kääntäneet uudelleen kuin korjailleet toisten tekstiä. ${ }^{6}$ 1920-luvulla WSOY:llä joka tapauksessa tehtiin Kurjien lisäksi muitakin vanhojen käännösten korjailtuja painoksia, esimerkiksi Lewis Wallacen Ben Hur ja Hall Cainen Kristitty ja Ikuinen kaupunki, joten mikään yksittäistapaus Kurjat ja sen korjailu ei ole.

Kurjien ensimmäisen osan korjauksia on tässä tarkasteltu Hugon esipuheen ja muutaman muun tekstikatkelman osalta. Tarkasteltavien lukujen otsikot ovat vuoden 1908 suomennoksen mukaan "Herra Myriel", "Herra Myrielistä tulee hänen ylhäisyytensä Bienvenu", "Hyvällä piispalla hankala hiippakunta", "Teot ja sanat sopusoinnussa keskenään” ensimmäisen kirjan ensimmäisestä osasta sekä "Fantine on onnellinen", 
"Javert on tyytyväinen", "Järjestysvalta tarttuu jälleen saaliiseensa" ja "Sopiva hauta" kahdeksannen kirjan lopusta. Ne korjaukset, joita Lehtosen suomentamaan ensimmäiseen osaan tehtiin, olivat tämän tarkastelun perusteella verraten vähäisiä. Teoksen alussa olevaan Hugon kaksisivuisen esipuheen suomennokseen tehtiin ainoastaan neljä muutosta. Kauvan-sana on korjattu kauan-muotoon, ryysyköyhälistö on korvattu proletaarilla, ilmaisu löytyy tietämättömyyttä on muutettu muotoon on tietämättömyyttä ja yksi jokasana on jätetty pois. Lauserakenteiden osalta inversioita on poistettu, mutta ei erityisen systemaattisesti. Yksittäisten tekstikohtien korjaukset liittyvät paljolti ortografiaan ja yleensä sellaisiin seikkoihin, joista kielenhuollossa oli pyritty tällä välin vakiinnuttamaan tiettyjä muotoja. Esimerkiksi oikeinkirjoituksen kohdalla yhdyssanoista on poistettu väliviivoja (pikku-lapsi > pikkulapsi, äiti-raukka > äitiraukka), sellaiset 1900-luvun alkuvuosina vielä tavalliset kirjoitusasut kuin ensimäinen ja kardinali on korvattu geminaatallisilla tai pitkän vokaalin sisältävillä varianteilla (ensimmäinen ja kardinaali).

Kurjien osalta mielenkiintoista on, että se päätyi osin korjailluksi, osin uudelleenkäännetyksi. Ensimmäisen osan korjaukset eivät näytä olevan niin suurisuuntaisia, että niiden perusteella voisi ajatella uudelleenkäännättämisen olleen tarpeellista. Jos korjausten tekijä oli Eino Voionmaa, hän saattoi kokea toisen suomentajan tekstin korjaamisen työlääksi ja mahdollisesti toivoi saavansa kääntää lopputekstin uudestaan. WSOY:n arkistosta ei valitettavasti löydy asiaan liittyvää kirjeenvaihtoa tai pöytäkirja-aineistoa.

On sellaisiakin esimerkkejä, joissa vanhoja käännöksiä on korjailtu mutta näin syntynyt versio on sitten kirjattu korjausten tekijän nimiin uutena käännöksenä ja alkuperäisen kääntäjän nimi on jäänyt pois. Tällaisia olivat esimerkiksi hyvin todennäköisesti Nikolai Gogolin Kuolleiden sielujen vuoden 1939 suomennos, joka bibliografisten tietojen mukaan olisi uusi suomennos, ja Selma Lagerlöfin Gösta Berlingin tarun vuoden 1922 ja sitä myöhemmät laitokset, jotka myös kulkevat uuden suomentajan nimellä. ${ }^{7}$ On kuitenkin selvää, että Kurjien toinen osa ei ole vain Lehtosen tekstin korjailua, vaan se on todella käännetty uudelleen. Seuraavassa toisen osan ensimmäisen kappaleen alku, jossa kuvataan saapumista Waterloon taistelun vanhalle tapahtumapaikalle. Vertailun vuoksi myös alkuteksti on otettu mukaan.

Ce qu'on rencontre en venant de Nivelles?

L'an dernier (1861), par une belle matinée de mai, un passant, celui qui raconte cette histoire, arrivait de Nivelles et se dirigeait vers La Hulpe. Il allait à pied. Il suivait, entre deux rangées d'arbres, une large chaussée pavée ondulant sur des collines qui viennent l'une après l'autre, soulèvent la route et la laissent retomber, et font là comme des vagues énormes. Il avait dépassé Lillois et Bois-Seigneur-Isaac. Il apercevait, à l'ouest, le clocher d'ardoise de Braine-l'Alleud qui a la forme d'un vase renversé. Il venait de laisser derrière lui un bois sur une hauteur, et à l'angle d'un chemin de traverse, à côté d'une espèce de potence vermoulue portant l'inscription: Ancienne barrière no 4, un cabaret ayant sur sa façade cet écriteau: Au quatre vents. Echabeau, café de particulier. 
Un demi-quart de lieue plus loin que ce cabaret, il arriva au fond d'un petit vallon où il y a de l'eau qui passe sous une arche pratiquée dans le remblai de la route. (Hugo 1862a, Tome IV, 73-74.)

1. Mitä matkustaja näkee Nivellesin tiellä?

Viime vuonna (1861), eräänä kauniina toukokuun aamuna, kulki muuan matkustaja, tämän tarinan kertoja, Nivellesistä la Hulpea kohti. Hän asteli jalan. Hän seurasi leveätä kivitettyä ajotietä, jota puurivit reunustivat ja joka milloin nousi, milloin laski niiden ylänteitten mukaan, mitkä täällä suunnatonten aaltojen lailla seurasivat toinen toistaan. Hän oli jo kulkenut Lilloisin ja Bois-Seigneur-Isaacin ohi. Hän huomasi lännessä Braine-l'Alleudin liuskakivikattoisen kirkontornin, joka näyttää alassuin käännetyltä saviastialta. Hiljattain oli hän sivuuttanut kummullaan törröttävän metsän ja muutaman poikkitien kulmassa kyhjöttävän kapakan, jonka päädyssä upeilivat sanat: Neljän tuulen kapakka. Echabeau, kahvila matkustavaisille. Lähellä kapakkaa näkyi vanha, lahonnut pylväs, jonka tauluun oli kirjoitettu: Entinen tulliasema n:o 4 .

Kapakasta kahdeksannes lieutä eteenpäin saapui hän pienen laakson pohjaan, missä puro solisee tien kohdalle laitetun kaarisillan alitse. (Hugo 1909, 9.)

1. Mitä Nivellesistä tullessa näkee?

Viime vuonna (1861), kauniina toukokuun päivänä, kulki eräs vaeltaja, se joka tätä tarinaa kertoo, Nivelles'istä tullen La Hulpeen päin. Hän kulki jalkaisin. Hän käveli kahden puurivin välissä leveää, kivettyä viertotietä, joka kumpuilee yli peräkkäisten kukkuloiden, jotka valtavina aaltoina nostavat ja taas laskevat tietä. Hän oli sivuuttanut Lillois'n ja Bois-Seigneur-Isaacin. Lännessä hän näki Braine l'Alleud'n kellotapulin, joka oli kuin nurinkäännetty maljakko. Hänen taakseen oli juuri jäänyt erään kukkulan metsä ja erään poikkitien risteyksessä lahoamassa olevan ristin vieressä, jossa oli kirjoitus: "Entinen vallitus n:o 4", ravintola, jonka seinässä oli kilpi: Neljän tuulen kahvila.

Neljännespeninkulman päästä tästä ravintolasta hän tuli pieneen alhoon, jonka pohjalla, tien penkereeseen sovitetun sillan alitse solisee vettä. (Hugo 1928, 7.)

Käännösten välillä on selviä eroja. Lehtonen esimerkiksi säilyttää ranskalaisen pituusmitan lieu, mutta muuttaa joidenkin sanojen sävyä runollisemmiksi kuin Voionmaa (vettä tarkoittava eau > puro / vesi; allait > asteli / kulki; portant > upeili / oli). Voionmaa näyttäisi pyrkivän tarkempaan ilmaukseen ja kenties myös lauseopillisesti lähemmäs lähtötekstiä.

Vuonna 1941 WSOY otti uuden painoksen vuoden 1927 laitoksen ensimmäisestä osasta. Vuosien 1927 ja 1941 painosten välillä ei ole eroja. Loppuosa, koko Voionmaan kääntämä osuus, jäi painamatta uudelleen. Sodan jälkeen vuosina 1945-1947 WSOY julkaisi uuden, kahteen kirjaan sidotun laitoksen, jonka nimiösivulla ilmoitettiin, että kyseessä oli lyhennetty suomennos. Kirjan tiedoissa ei kerrota, kuka lyhentämisen on tehnyt, mutta Fennica-tietokannassa "supistajaksi" ilmoitetaan Reino Rauanheimo. 
Suomentajien nimet mainittiin kirjassa vasta nimiösivun takapuolella, ja kirjan myöhemmistä painoksista ne on jätetty kokonaan pois. Uuden laitoksen lukija ei siis tiedä, kenen suomennosta hän lukee.

Uusimman laitoksen lyhentely on tapahtunut niin, että käännöksestä on poistettu kokonaisia tekstikatkelmia sen sijaan, että tapahtumat olisi kerrottu lyhennellen ja toisin sanoin esittäen. Alkuperäisen teoksen hyvin monitasoinen osien, kirjojen ja lukujen numerointi on häivytetty, lukuja on yhdistelty ja osa niistä on poistettu. Lisäksi on poistettu sieltä täältä eripituisia jaksoja ja lauseita. Poistetut kohdat ovat sellaisia, joissa valotetaan henkilöiden luonnetta heidän toimiensa kautta, heidän keskustelujaan sekä pääjuoneen suoraan liittymättömiä sivujuonteita. Myös kuvailevia tai lisätietoa antavia sivulauseita on poistettu. Esimerkiksi V osan ensimmäisen kirjan ensimmäinen luku, "Saint-Antoinen Charybdis ja Templen Scylla", on jätetty kokonaan pois, samoin toisen luvun ensimmäinen kappale. Jäljelle jätettyä tekstiä itsessään ei ole muutettu, mutta poistoja ei ole merkitty, eikä niiden vuoksi ole päädytty myöskään millään lailla muokkaamaan tekstiä kuten usein lyhennelmissä tehdään koherenssin lisäämiseksi. Muokkaus ei olisi sinänsä ollut tarpeenkaan tässä tapauksessa, koska Hugon tekstin monet sivujuonteet näyttävät olevan irrotettavissa ilman että pintatason koherenssi kärsii. Karkean sanamääriin perustuvan arvion perusteella kokonaistekstin määrä on vähentynyt noin kolmasosalla. Sivuja on vuosien 1927-1931 painoksessa 1815, ja vuosien 1945-1947 laitoksessa 978. Tämä lyhennelmä on se versio, joka elää edelleen lukuisten uusintapainosten kautta ja on ainoa kirjakaupoista ja useimmiten yleisistä kirjastoistakin saatavilla oleva suomennos. Viimeisin, 14. painos on vuodelta 1999.

Sanomalehtikritiikki 1940-luvun lyhennelmästä oli pääosin positiivista, ja monet arvioijat tuntuivat pitävän lyhentämistä jopa hyvänä ratkaisuna. Hugon "tendenssimäisyyttä” pidettiin vanhentuneena, minkä vuoksi lyhentäminen annettiin anteeksi ja sitä jopa arvostettiin. Hugon teosten lyhentelystä on esimerkkejä muuallakin. Chris Bongie $(2005,1)$ siteeraa Hugon elämäkerran kirjoittanutta Graham Robbia, jonka mukaan Kurjista on englanniksi saatavilla vain "reikäjuustokäännös" ("a Swiss cheese of unavowed omissions"), surullisen typistetty teksti, jonka aukot eivät paljasta puuttuvia tekstikohtia. Ruotsiksi taas Kurjista ilmestyi vuonna 1906 Hugo Gyllanderin 650-sivuinen lyhennelmä, ja vuonna 1947 Gemma Funtek-Snellmanin 445 sivua pitkä lyhennelmä, josta otettiin toinen painos 1970. Gyllanderissa tieto lyhentämisestä mainitaan, mutta Funtek-Snellmanin kirjasta puuttuvat ruotsintajan nimi ja maininta lyhentämisestä, vaikka kirja on ilmestynyt juhlavasti sarjassa Berömda romaner. Hugon oma jako osiin, kirjoihin ja lukuihin on pelkistetty niin, että kirjassa on ainoastaan lukuja, joita on yhteensä 35. Funtek-Snellman ja Gyllander ovat molemmat lyhennellessään turvautuneet myös parafraasiin poistojen lisäksi. Viimeisin ilmestynyt ruotsinnos on Jakob Gunnarssonin käännöksen vuonna 1998 ilmestynyt toinen painos, joka sekin on lyhennelmä (ja muistuttaa ainakin osin Gyllanderin tekstiä). 


\section{Klassikot, käännökset ja tekstuaaliset kerrostumat}

Klassikkouden ajatellaan usein määrittyvän jonkinlaisista laadullisista, sisäisistä kriteereistä käsin. Toisaalta ulkoiset tekijät vaikuttavat siihen, mitä kirjoja pidetään esillä, mitä nostetaan esiin ja suomennetaan uudelleen. ${ }^{8}$ Näin joillekin teoksille kasaantuu käännöskertoja, toisille ei. Ne, joista uuden käännöksen sijaan tehdään uudelleenpainoksia, jatkavat myös elämäänsä - mutta usein muokattuina tai lyhenneltyinä, mikä jätetään kertomatta. Lisäksi tekstin korjaukset voivat olla monenlaisia ja monista eri syistä tehtyjä. Kurjien 1920-luvun korjaukset liittyivät kirjakielen kodifioinnin mukanaan tuomiin muutoksiin, mutta muita korjattuja käännöksiä tutkittaessa huomaa, että korjaajan kädenjälki voi myös olla toisenlainen. Korjaaja voi muuttaa tekstin tyyliä, esimerkiksi ylevöittää sitä. Termistö on kirjavaa: kirjojen etulehdillä saatetaan puhua korjatusta, tarkistetusta, uudistetusta tai toimitetusta käännöksestä. Lisäksi "tarkistus" jonkin teoksen kohdalla on tarkistusta alkuteokseen verraten, mutta toisen teoksen kohdalla tarkistusta kielenhuollon normien suhteen. Tässä on huomattava, että myös alkuperäisiä suomenkielisiä teoksia on muokattu vuosien varrella, eikä niissäkään usein ole merkintää tekstin korjailusta.

Kurjat ja sen suomentamisen historia tuovat esiin monenlaisia tekstuaalisia ja metodologisia ongelmia, joita ei käännöstutkimuksessakaan ole vielä riittävästi käsitelty. ${ }^{9}$ Alkuteksti ei ole aina pysyvä ja stabiili, eikä käännöskään ole yksinkertainen määritellä ja saumaton luokitella. Kahden perinteisen tutkimuksellisen kategorian, lähtötekstin ja käännöksen, lisäksi saattaa olla olemassa ensinnäkin monenlaisia eri versioita alkutekstistä. On piraattipainoksia, kirjailijan itsensä muokkaamia versioita, ja virallisen sensuurin tai muun muokkauksen ja lyhentelyn kohteeksi joutuneita tekstejä. Lisäksi kääntäjällä on voinut olla käytössään sekä muunkielisiä käännöksiä että edeltäviä samankielisiä käännöksiä, joihin uusi kääntäjä voi reagoida tietoisesti tai jopa osin tiedostamattomasti. Tuloksena on käännöksiä, joissa on moninkertaisia tekstuaalisia kerrostumia. Voidaan myös kysyä, missä menee raja vanhan käännöksen korjailun ja uuden käännöksen välillä - ja minkälaisia esioletuksia omiin tutkimusasetelmiimme sisältyy, jos haluamme nähdä käännöksen "uutena”.

Painosten suuren määrän vuoksi ja siksi, että tekstit ovat maantieteellisesti hajallaan eri maissa, versioiden suhdetta toisiinsa on usein mahdoton kattavasti selvittää. Kuten tämänkin artikkelin esimerkeistä käy ilmi, myös bibliografiat ja tietokannat ovat puutteellisia ja osin harhaanjohtavia, kuten kaikki inhimillisen pyrkimyksen tulos. Vaillinainenkin kartoitus kuitenkin tuo esiin kysymyksiä tekstin alkuperästä ja myös kyseenalaistaa suhdettamme "ikuisiin" lähtöteksteihin ja muuttumattomiin kategorioihin. 


\section{Viitteet}

${ }^{1}$ Ranskalaisen realismin pohjoismaisia käännöksiä sisältävästä BREFS-tietokannasta (http://www.hf.uio.no/ilos/forskning/brefs/) ei löydy mitään oleellista lisätietoa Kurjien pohjoismaisista laitoksista. Kääntäjämerkintä puuttuu BREFS-tietokannan tavoin myös laitoksen Kansalliskirjaston kokoelmissa säilytettävästä kappaleesta.

${ }^{2}$ Katkelman ranskankielinen alkuteksti kuuluu seuraavasti: La révolution survint, les événements se précipitèrent, les familles parlamentaires décimées, chassées, traquées, se dispersèrent. M. Charles Myriel, dès les premiers jours de la révolution, émigra en Italie. Sa femme y mourut d'une maladie de poitrine dont elle était atteinte depuis longtemps. Ils n'avaient point d'enfants. Que se passa-t-il ensuite dans la destinée de M. Myriel? L'écroulement de l'ancienne société française, la chute de sa propre famille, les tragiques spectacles de 93, plus effrayants encore peut-être pour les émigrés qui les voyaient de loin avec le grossissement de l'épouvante, firent-ils germer en lui des idées de renoncement et de solitude? (Hugo 1862a, 8.)

${ }^{3}$ Ruotsintaja on merkinnyt oman alaviitteensä lyhenteellä ”ö.a." (översättarens anmärkning), mikä oli yleinen käytäntö. Myös suomentajilla oli tapana kirjoittaa omia alaviitteitään käännökseen, ja he merkitsivät ne usein lyhenteellä "Suom. muist." tai "Suom. huom." (ks. Paloposki 2010, 94). Jos suomentajan alaviitteen perässä ei ollut tällaista lyhennettä, alaviite ei välttämättä ollut hänen omansa, vaan se oli saattanut olla jo suomentajan käyttämässä lähdetekstissä. Alaviitteet ovat voineet tekstiin tulla jo kirjailijan tai aiemman kääntäjän myötä. Merkitsemiskäytännöt ovat vaihdelleet jonkin verran, joten niiden perusteella ei voi tehdä johtopäätöksiä vertailematta painoksia toisiinsa. Kurjien tapauksessa kyseessä oli siis ruotsintajan alaviite, jonka suomentaja oli kääntänyt. Vuoden 1862 ruotsinnoksessa ei tässä kohden ollut alaviitettä, ja käännös on muutenkin varsin erilainen, joten se ei liene ollut suomentajan käytössä.

${ }^{4} \mathrm{H}: n$ henkilöyttä en ole kyennyt selvittämään. Nimimerkki ja aihepiirin samankaltaisuus sopisivat yhteen Jalmari Hahlin kanssa. Hän oli kirjoittanut edellisvuonna ilmestyneeseen Lucrezia Borgiaan esipuheen. Esipuheet ovat kuitenkin hyvin erityylisiä ja Hahl viittaa aivan muihin lähteisiin kuin " $\mathrm{H}$ ".

${ }^{5}$ Lehtosen kirjallisen uran alkuvaiheet olivat sekä hänen omien kommenttiensa että arvostelujen valossa niin suomentamisvoittoisia, että voisi helposti luulla kyseessä olevan kaksi eri ihmistä - Vihtori Lehtonen ja J. V. Lehtonen. Edes Fennica-tietokanta ei anna vihjeitä siitä, että kyseessä on sama henkilö, joten J. V. Lehtosen nimellä etsittäessä Hugo-suomennosta ei sieltä löydy. Kansallisbiografia (SKS, osa 6) ei mainitse Lehtosen varhempaa käännöstuotantoa. Suomen kirjailijat -matrikkeli listaa Vihtori Lehtosen nimellä tehdyn Juan Valeran Kiusaussuomennoksen J. V. Lehtosen kohdalle, muttei Kurjia eikä Lehtosen tekemää Raleighsuomennosta.

${ }^{6}$ Esimerkiksi Aatto Suppanen ja Juhani Konkka ovat kirjeenvaihdossaan pohtineet jo käännetyn tekstin korjaamisen hankaluutta.

${ }^{7}$ Näistä tarkemmin ks. Paloposki ja Koskinen (tulossa). Todennäköisesti on kyse tapauksista, joissa tarkoitus ei ole ollut esittää tekstiä uutena käännöksenä vaan korjattuna versiona, mutta korjaaja on vahingossa merkitty suomentajaksi.

${ }^{8}$ Klassikkouden määrittelemisestä käännöskirjallisuudessa ks. Paloposki ja Koskinen (tulossa). ${ }^{9}$ Ks. kuitenkin esimerkiksi Pym 1998, 68-70 ja Bassnett 2000 erilaisista käännösversioista ja niiden luokittelusta. 


\section{Aineistolähteet}

Alkuteos ja käännökset

Hugo, victor i 862A: Les Misérables. Tomes I-XVII. Bruxelles: Paetz. (Teoksen viisi osaa Fantine, Cosette, Marius, L'Idylle Rue Plumet \& L'Epopée Rue St. Denis ja Jean Valjean on ensin jaettu 17 niteeseen, jotka puolestaan on yhdistetty neljäksi sidokseksi.) HUGO, victor I 862B: Sambällets olycksbarn. Övers. C. J. Backman. Stockholm: Hierta. HUgO, victor I888-i889: Samhällets olycksbarn. (Ei ruotsintajatietoa.) Stockholm: Hierta.

HUgo, victor I 895: Sambällets olycksbarn. (Ei ruotsintajatietoa.) Tammerfors: Nya tryckeribolagets tryckeri. (Teoksen alku, 112 sivua.)

HUgO, VICTOR I 896-I 897: Yhteiskunnan onnettomat. Suom. J. J. Tampere: Tampereen kp.-osakeyhtiö. (Teoksen alku, 448 sivua.)

HUGO, VICTOR I906: Sambällets olycksbarn. En galärslafs historia. Öfs. Hugo Gyllander. Stockholm: Fröléen \& Komp. (Lyhennetty laitos.)

HUgO, victor I908-I809: Kurjat I-II. Suom. Vihtori Lehtonen. Viipuri: Kansan Romaanikirjasto. (Osat Fantine ja Cosette.)

HUgO, victor I927-I93 I: Kurjat I-V. Suom. Vihtori Lehtonen ja Eino Voionmaa. Porvoo: WSOY. (Osat Fantine, Cosette, Marius, Idylli Plumet- ja Epopeia Saint-Deniskadun varrella ja Jean Valjean.)

hUgO, victor I94I: Kurjat I. Suom. Vihtori Lehtonen. Porvoo WSOY. (2. painos.)

HUgo, victor I945-1947: Kurjat I-II. Porvoo: WSOY. (Koko teoksen lyhennetty painos kahdessa sidoksessa; lukuisia uusintapainoksia.)

HUGO, victor 1947: Samhällets olycksbarn 1-2. Övers. Gemma Funtek-Snellman. Berömda romaner 7-8. Helsingfors: Söderström.

HUGO, VICTOR I998: Samhällets olycksbarn. Övers. Jakob Gunnarsson. Andra upplaga. Stockholm: Klassikerförlag.

Arkistoaineisto

KONKKA, JUHANI: kirjeet Werner Söderström Osakeyhtiölle. Suomalaisen kirjallisuuden seuran kirjallisuusarkisto, Juhani Konkan arkisto: Kirjekokoelma 835 (C. Kirjeet: 25: $1-68)$.

Lehtonen, J. v.: kirjeet A. V. Koskimiehelle 23.3.1903 ja 17.8.1903. Suomalaisen kirjallisuuden seuran kirjallisuusarkisto. Kirjearkisto, Mf 2005:1, rulla 1 (143144:71:1:c).

LeHtonen, J. v.: kirjeet Kaarle Krohnille 27.7.1909 ja 6.4.1910. Suomalaisen kirjalli- 
suuden seuran kirjallisuusarkisto. Kirjearkisto, III:39:1-10.

SUPPANEN, AATTO: kirjeenvaihto Werner Söderström Osakeyhtiön kanssa. WSOY:n arkisto.

\section{Kirjallisuus}

BASSNETT, SUSAN 2000: Adventures across time: Translational transformations. - On Translating French Literature and Film II. Ed. Myriam Salama-Carr. Amsterdam/ Atlanta: Rodopi, 155-170.

BONGIE, CHRIS 2005: Victor Hugo and "The Cause of Humanity". Translating Bug-Jargal (1826) into The Slave-King (1833). The Translator 11:1, 1-24.

HELLEMANN, JARL 2007: Kustannustoiminta kansainvälistyy. - Suomennoskirjallisuuden historia I. Toim. H. K. Riikonen, Urpo Kovala, Pekka Kujamäki ja Outi Paloposki. Helsinki: SKS, 336-345.

HÄGGMAN, KAI 2008: Paras tawara maailmassa. Suomalainen kustannustoiminta 1800luvulta 2000-luvulle. Helsinki: Otava.

HäGgman, KaI 200I: Piispankadulta Bulevardille. Werner Söderström Osakeyhtiö 18781939. Helsinki: WSOY.

JÄNTTI, YRJÖ A. I928: Werner Söderström osakeyhtiö: viisikymmenvuotinen kustannustoiminta 1878-1928. I-II. Porvoo: WSOY.

KANGAS, AINO I988: Muodot vakiintuvat, merkitykset karkaavat. Kielenhuoltoa Virittäjässä 1920-luvulta nykypäivään. Pro gradu -tutkielma. Helsingin yliopisto: suomen kielen laitos.

KIURU, SILVA S.A.: [kommentteja Hugon Hernani-suomennokseen]. < http://kaino. kotus.fi/korpus/1800/meta/hannikainen/hernani1870_rdf.xml> (31.5.2010)

KOSKINEN, YRJÖ [Y. K.] I 877: Saara Elisabet Wacklin. Satanen Muistelmia Pohjanmaalta. [kirja-arvio]. Kirjallinen Kunkauslehti 2/1877, 31-34.

LEHTONEn, J. v. I9I7: Victor Hugo. Merkkimiehiä 8-9. Porvoo: WSOY.

PALOPOSKI, OUTI 20Iо: The Translator's Footprints. - Translators' Agency. Ed. Tuija Kinnunen and Kaisa Koskinen. Tampere Studies in Language, Translation and Culture. Series B4. Tampere: Tampere University Press, 1-22. <http://tampub.uta.fi/tup/978951-44-8082-9.pdf> (31.5.2010)

PALOPOSKI, OUTI 2007: Suomentaminen ja suomennokset 1800-luvulla. - Suomennoskirjallisuuden historia I. Toim. H. K. Riikonen, Urpo Kovala, Pekka Kujamäki ja Outi Paloposki. Helsinki: SKS, 102-126.

PALOPOSKI, OUTI JA KAISA KOSKINEN (TULOSSA): Sata kirjaa, tuhat suomennosta. Julkaisematon käsikirjoitus.

PyM, ANTHONY 1998: Method in Translation History. Manchester: St. Jerome.

SAKARI, ELLEN I986: Ranskalaisesta käännöskirjallisuudesta autonomian aikana. - 
Maailmankirjallisuuden ja sen klassikkojen suomentamisesta I. Toim. Urpo Kovala. Jyväskylän yliopiston kirjallisuuden laitos. Monisteita 30. Jyväskylä: Jyväskylän yliopisto, 82-119.

suOMalainen, SAmuli i 884: Onkohan A. Kiven Nummisuutarit todellakin ansiokas näytelmä? Laatokka 6.4.1884, 1-2.

SÖDERHJELM, WERner I 88 5: Victor Hugo. Valvoja 1885, 325-330.

Tarkiainen, Viljo [V. T.] 1909: Valera, Juan. Kiusaus. [kirja-arvio]. Valvoja 1909, 519 520.

TARKKA, PEKKA I980: Otavan historia. Toinen osa 1918-1940. Helsinki: Otava.

TUOMINEN, LAURA 2004: Ranskalainen kirjallisuus Valvojassa 1800-luvun lopulla. Yhteistä kieltä tekemässä. Toim. Lea Laitinen, Katja Huumo ja Outi Paloposki. Helsinki: SKS, 341-371.

vandersChelden, ISABelle 2000: Why Retranslate the French Classics? The Impact of Retranslation on Quality. - On Translating French Literature and Film II. Ed. Myriam Salama-Carr. Amsterdam/Atlanta: Rodopi, 1-18.

VIRTANEN, ARTTURI I958: Suomen kirjakaupan ja kustannustoiminnan vaiheita. Helsinki: Suomen kustannusyhdistys.

ZWEYGBERGK, OLA I958: Om bokförlag och bokförläggare i Finland: en översikt. Helsingfors: Finlands förlagsförening. 